stated that unfortunately there is no possibility of a licence being obtained for the extension to the west wing of the Museum, though, on the other hand, it is possible that one may be issued for a smaller building to serve as a beginning of a museum block at the Welsh Folk Museum, St. Fagans. This would permit the removal to St. Fagans of folk-life material and lead to a reorganization of the first-floor galleries at Cardiff. The freeing of the circular gallery for temporary exhibitions would be a welcorne action. Work in the geological gallery has been devoted towards improving the appearance but not the essential range and purpose of the exhibits. At the Welsh Folk Museum the chief activity has been again the re-erection of buildings. The Montgomeryshire house is now thatched and wattled, and the stone house from Gower is nearing completion. An upland farmhouse from Dyffryn Claerwen, Radnorshire, has been accepted and will provide the Museum with its first complete unit of stable, cowhouse and dwelling.

National Research Council of Canada : Awards for 1954-55

THE National Research Council of Canada has granted 236 scholarships for 1954-55, totalling in value 283,200 dollars. These scholarships include 75 bursaries worth 800 dollars each, 103 studentships worth 1,100 dollars each and 21 fellowships worth 1,400 dollars each, all of which are to be held in Canada. Special scholarships awarded for studv abroad include twenty awards worth 1,900 dollars each, which will be held in the following countries: ten in the United States, eight in the United Kingdom, one in France and one in Sweden. Seventeen overseas postdoctorate fellowships worth 2,500 dollars each have been granted for work in the following countries : twelve in the United Kingdom, two in Sweden, one in Denmark, one in France and one in the Netherlands.

\section{Colonial Service: Recent Appointments}

THE following appointments have been made in the Colonial Service : D. W. Malcolm (principal assistant secretary, Tanganyika), secretary for agriculture and natural resources, 'Tanganyika; A. F. Mackenzie (deputy director of agriculture, Sierra Leone), director of agriculture, British Guiana; F. E. Hughes (deputy chief conservator of forests, Gold Coast), chief conservator of forests, Gold Coast; I. G. John (assistant director, Malayan Meteorological Service), director Malayan Meteorological Service; N. S. Sandeman (assistant game warden, Uganda), game ranger, Kenya; A. J. Vincent, assistant conservator of forests, Federation of Malaya ; A. Crosbie, veterinary officer, Northern Rhodesia; Miss E. R. Blydenstein, meteorologist, East Africa High Commission; J. O. Goss, agricultural officer, Nigeria; B. G. Hoare, agricultural officer, Gold Coast; A. R. Longhurst, scientific officer, West African Fisheries Research Institute, Sierra Leone; W. G. Owen, geographer, Hydrological Survey Department, Uganda; J. F. Truswell, geologist, Nigeria.

\section{Announcements}

THE Atomic Energy Authority announces that Mr. W. R. J. Cook, chief of the Royal Naval Scientific Service since 1950 (see Nature, 166, 135; 1950), has been released from his present post to take up that of deputy director of the Atomic Weapons Research Establishment, Aldermaston, the director of which is Sir William Penney.
The Lister Medal for 1954, which is given in recognition of distinguished contributions to surgical science, has been awarded to Mr. Victor Ewings Negus, consulting surgeon to the Ear, Nose and Throat Department of King's College Hospital, London, in recognition of his services to the advancement of knowledge in the surgery of the nose and throat by means of his researches into the comparative anatomy and physiology of the larynx and para-nasal sinuses. This is the eleventh occasion of the award, which is made by a committee representative of the Royal Society, the Royal College of Surgeons of England, the Royal College of Surgeons in Ireland, the University of Edinburgh and the University of Glasgow.

The College of Physicians of Philadelphia has awarded the Alvarenga Prize for 1954 to Dr. DeWitt Stetten, jun., associate director in charge of research, National Institute of Arthritis and Metabolic Diseases, National Institutes of Health, Bethesda, Maryland, for his outstanding contributions to knowledge of metabolic diseases. The Alvarenga Prize was established by the will of Pedro Francisco DaCosta Alvarenga, of Lisbon, an associate fellow of the College, to be awarded annually on the anniversary of his death on July 14, 1883.

THE Faraday Society will be holding a general discussion on "Coagulation and Flocculation" in the Department of Chemistry, University of Sheffield, during September 15-17, under the chairmanship of Prof. R. G. W. Norrish, president of the Society. The twenty-nine papers to be presented will be divided into three groups, with introductory addresses for each group by the following : classical coagulation, Prof. J. T. G. Overbeek (Utrecht) ; coacervation, Dr. A. S. C. Lawrence (Sheffield); and biological systems, Dr. J. R. Marrack (Cambridge). Advance proofs of all the papers will be available about the end of this month. Applications for accommodation (to be made not later than September 6) and all other inquiries should be sent to the Secretary of the Faraday Society, 6 Gray's Inn Square, Gray's Inn, London, W.C.1.

THE Oil and Colour Chemists' Association will be holding a symposium on "Rheology and Settlement of Pigmented Systems" on September 23 in the Chemistry Theatre of University College, Gower Street, London, W.C.1. In the morning Prof. Stacey G. Ward will give a lecture on properties of welldefined suspensions of solids in liquids, and Mr. J. Pryce-Jones on the rheological state of a suspension as a criterion for the study of the flow and settlement of paints. The afternoon session will be devoted to a discussion on these two papers. The symposium will be open to non-members on application to the general secretary of the Association, R. H. Hamblin, Memorial Hall, Farringdon Street, London, E.C.4, from whom further information can be obtained.

The ninth Annual Calorimetry Conference in the United States will be held in the General Electric Research Laboratory, The Knolls, Schenectady, New York, during September 17-18, under the chairmanship of Dr. E. J. Prosen (National Bureau of Standards, Washington, D.C.). The conference is open to all, without registration fees. Further information can be obtained from Dr. Warren DeSorbo, General Electric Company, Metallurgy Research Department, Research Laboratory, P.O. Box 1088, Schenectady, New York. 